Proceedings of the International Conference on Teaching, Education and Learning Conference, Vol. 1, 2021, pp. 14-29

Copyright (C) 2021 iConferences

ISSN 2820-2155

DOI:https:/doi.org/10.32789/tel.2021.1002

Comparative Study of E-Learning Readiness and Socio-Economic Factors during Covid-19 Pandemic: Evidence from High School Students in Urban and Rural Areas of Indonesia

Moch. Bambang Sulistio

Yonsei University, South Korea, moch.bambang@yonsei.ac.kr 


\title{
COMPARATIVE STUDY OF E-LEARNING READINESS AND SOCIO-ECONOMIC FACTORS DURING COVID-19 PANDEMIC: EVIDENCE FROM HIGH SCHOOL STUDENTS IN URBAN AND RURAL AREAS OF INDONESIA
}

\begin{abstract}
As the global pandemic of COVID-19 spreads enormously, educational institutions were forced to close down in most countries, affecting $91 \%$ of pupils and causing massive disruption to the education sector. In Indonesia, 62, 5 million students from pre-primary to higher education are forced to shift from conventional learning to a complete move into e-Learning. This study sought to explore students' readiness to cope with online learning both in urban and rural areas of Indonesia and to find the relation whether socio-economic factors during pandemic affect their e-learning readiness. The theory underpinning the study was the e-Learning Readiness theory which measures eight dimensions: human resource, financial, technological, equipment, content, psychological, sociological, and environmental readiness. An online survey was conducted, and a total of 1.260million students in urban and 846 students in rural areas participated in the study. The data were analyzed using multiple regression and confirmatory factor analysis (CFA). This study reveals that students in urban areas are categorized as ready, but they need improvements in several aspects with the readiness index 3 , 47. In contrast, students are not ready in rural areas and need several improvements with index 3 , 01 . The study also highlights that basic IT skills competencies are critical for the preparedness of elearning and should be taught to students. Future studies could analyze whether ICT training will significantly impact their perceives and acceptance of students' e-learning readiness, especially in rural areas, after training has been conducted.
\end{abstract}

Keywords: E-learning, readiness, students, digital learning, COVID-19 pandemic

\section{Introduction}

Since the COVID-19 pandemic has spread widely, it has impacted practically every facet of our lives, including the field of education. In most countries, educational institutions were forced to close, affecting 91 percent of students and causing major upheaval in the education sector. The number is equivalent to 1.6 billion students who cannot attend face-to-face interactions in schools since March 2020 and are forced to convert to distance learning. Among them, 463 million students remain suspended from school due to the lack of equipment needed (Alqahtani \& Rajkhan, 2020; UNICEF,2020).

In regards to dealing with the pandemic, the Government around the world is forced to make a transformative shift from conventional learning and provide broadcast and design policy in digital learning. For instance, the Government of Ukraine rolled out the online platform so-called "Learning Passport" to ensure students received proper materials. While in Rwanda, 3 million students followed through the radio as the most proper channel to spread the learning materials. Even in a conflict country like Syria, which enters its tenth year of conflict, this pandemic leaves them at high risk of dropping out, where self-learning and printed textbooks are the only way to survive (UNICEF,2020a; UNICEF, 2020b). 


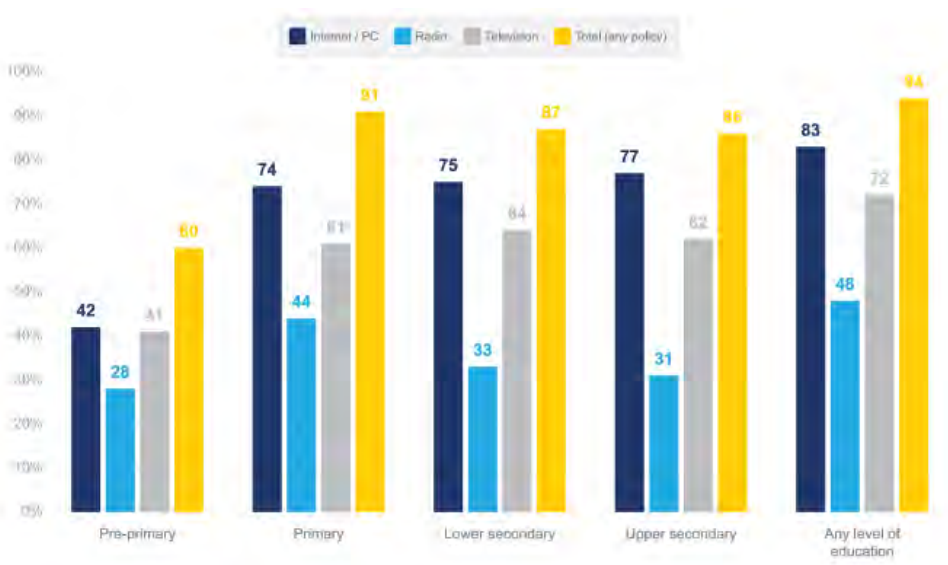

Figure 1. Share of countries implemented digital learning amidst pandemic Covid-19 (UNICEF,2020)

In the means of communication, remote learning policies through the Internet have become the most chosen policy by the Government worldwide. The share is higher than television and radio, in all levels of education. On average, $83 \%$ of governments choose the Internet as the medium to transfer learning, compared to television with $72 \%$ and radio with $48 \%$ (UNICEF,2020b), as seen in fig.1. To cope with digital learning, students ought to have assets that allow them to learn remotely via digital or broadcasts. However, UNICEF (2020b) posited that almost 31\% of schoolchildren around the globe could not follow digital learning due to a lack of having the devices. In addition, some $40 \%$ of countries also did not provide proper distance learning for pre-primary education.

As most governments choose to transfer learning through the Internet, applying information technology in this field is critical. This technology is renowned as e-Learning (Hoq, 2020). Electronic learning (e-learning) is one of the most promising distance learning platforms that the Government deals with the pandemic. A total of 122 e-learning portals have been created all over the globe since the pandemic has occurred (UNESCO, 2020). In addition, before the pandemic occurred, e-learning was a platform that was growing roughly $16,4 \%$ yearly by teachers and students worldwide. Yet, after this pandemic, the number is believed to experience significant growth (Alqahtani \& Rajkhan, 2020).

Since March 2020, Indonesia's students, parents, and teachers have grappled with school closures affecting 62.5 million students from pre-primary to higher education. The Government tries to utilize e-learning to keep the student on track with the standard curriculum. The Ministry set two online platforms as national platforms for learning. First is Rumah Belajar, a Learning Management System for digital classrooms involving students and teachers to participate and communicate in the distance, equipped with multimedia and online labs. The second one is SPADA, an e-learning platform provided free by the Government to students sitting on tertiary education (Lina,2020).

However, the digital divide still becomes a barrier for students in most developing countries like Indonesia. Recent research in developing countries posited that access to electrical power, computers, utilities (Internet connectivity, limited budgets, limited IT support resources), insufficient financial capital, challenge regulatory supervision, properly qualified teachers, local capacity building, cultural 
and socially relevant learning materials, and practices are all problems to be tackled in offering on-site e-learning or Massive Open Online Learning Courses (MOOCs) (Hillier, 2018; Aung \& Khaing, 2015; Atanda \& Ahlan, 2014).

As the biggest archipelago country, Indonesia needs to cope with the telecommunication infrastructure problems. Based on the UN e-Government Survey 2020, Indonesia has the lowest score in the telecommunication infrastructure index compared to its online service and human capital index (UN, 2020). In addition, on average, the country still ranks low in the information and communication technology (ICT) Development Index (IDI) 2019; as table 1 shows, the country placed 7th in the ASEAN region, with only $45,7 \%$ of the population having access to the net. In fact, the indicator shows the country is under the average of ASEAN countries in the overall IDI index, including significant variables like average bandwidth, individual access who access the Internet, households to access the Internet, and fixed broadband subscriptions.

Table 1: Infrastructure Telecommunication Statistic in Regions (ITU,2017; World Bank,2020)

\begin{tabular}{|c|c|c|c|c|c|c|c|c|c|c|c|c|}
\hline \multirow[t]{2}{*}{ No } & \multirow{2}{*}{$\begin{array}{l}\text { IDI } \\
2017 \\
\text { Rank }\end{array}$} & \multirow[t]{2}{*}{ Country } & \multirow{2}{*}{$\begin{array}{l}\text { IDI } \\
\text { Index }\end{array}$} & \multirow{2}{*}{$\begin{array}{l}\text { Average } \\
\text { International } \\
\text { Internet } \\
\text { Bandwidth } \\
\text { (MB/s) 2017 }\end{array}$} & \multicolumn{2}{|c|}{$\begin{array}{l}\text { Individuals with } \\
\text { Internet Access (\%) }\end{array}$} & \multicolumn{2}{|c|}{$\begin{array}{l}\text { A household with } \\
\text { Internet Access }(\%)\end{array}$} & \multicolumn{2}{|c|}{$\begin{array}{l}\text { Mobile phone } \\
\text { subscription/100 } \\
\text { inhabitants }\end{array}$} & \multicolumn{2}{|c|}{$\begin{array}{l}\text { Fired brosidband } \\
\text { subseription/ } \\
100 \text { inhabitants }\end{array}$} \\
\hline & & & & & 2017 & 2019 & 2017 & 2019 & 2017 & 2019 & 2017 & 2019 \\
\hline 1 & 18 & Singapore & 8.05 & 12.3 & 81.0 & 88.9 & 91.1 & 92.1 & 146.9 & 156.4 & 25.5 & 25.8 \\
\hline 2 & 53 & Brunei Darussalam & 6.75 & 1.0 & 75.0 & 95.0 & 75.0 & 76.0 & 120.7 & 128.6 & 8.3 & 12.5 \\
\hline 3 & 63 & Malaysia & 6.38 & 0.5 & 78.8 & 84.2 & 76.9 & 85.7 & 141.2 & 139.6 & 8.7 & 9.3 \\
\hline 4 & 78 & Thailand & 5.67 & 0.6 & 47.5 & 66.7 & 59.8 & 64.4 & 172.7 & 186.2 & 10.7 & 14.5 \\
\hline 5 & 101 & Philippines & 4.67 & 0.5 & 55.5 & 43.0 & 39.1 & 42.7 & 109.2 & 154.8 & 5.5 & 3.9 \\
\hline 6 & 108 & Vietnam & 4.43 & 1.1 & 46.5 & 68.7 & 25.9 & 27.3 & 128.0 & 141.2 & 9.9 & 15.3 \\
\hline 7 & 111 & Indonesia & 4.33 & 0.3 & 25.4 & 47.7 & 47.2 & 57.3 & 149.1 & 127.5 & 1.9 & 3.5 \\
\hline 8 & 128 & Cambodia & 3.48 & 0.3 & 25.6 & 41.0 & 26.0 & 21.0 & 124.9 & 129.9 & 0.6 & 1.1 \\
\hline 9 & 135 & Myanmar & 3.00 & 0.1 & 25.1 & 24.0 & 24.4 & 28.3 & 89.3 & 114.0 & 0.1 & 0.2 \\
\hline 10 & 139 & Lao P.D.R. & 2.91 & 0.2 & 21.9 & 26.0 & 18.7 & 24.5 & 55.4 & 60.8 & 0.3 & 1.1 \\
\hline \multicolumn{3}{|c|}{ ASEAN } & 4.96 & 1.7 & 48.2 & 58.5 & 48.4 & 51.9 & 123.7 & 133.9 & 7.1 & 8.7 \\
\hline \multicolumn{3}{|c|}{ KOREA } & 8.85 & 28.55 & 92.7 & 96.1 & 99.1 & 99.2 & 122.6 & 134.5 & 41.1 & 42.7 \\
\hline
\end{tabular}

In application to education sectors, obstacles related to electricity flow and internet access are a major challenge to the equal distribution of educational facilities across Indonesia. Areas that do not yet have electricity and access to the Internet need a particular strategy so that educators and students in these areas can get educational facilities equal to other regions. There are still 42.159 schools across the country which does not have access to the Internet, and 8.522 schools do not have electricity due to untouched access to the area since the pandemic occurred (MoE,2020).

Another problem that can be considered is that there is still a gap in both facilities and capacity training in both urban and rural areas. The percentage of schools with access to the Internet in the urban area is higher than in the rural area. In urban areas, $80,57 \%$ of schools have access to the Internet, while only $66,67 \%$ of them have access to the web in rural areas. Students who receive ICT competence training in urban areas are 53,96\%, compared to a rural area with only $28,33 \%$. Furthermore, only 2,39\% of teachers surveyed ever had training in the urban area, and the number is narrowed to $0,62 \%$ in the rural area (Central Bureau of Statistic, 2018). 
Based on the fact above, this paper wants to address the gap of e-learning readiness between urban and rural areas in Indonesia during the Covid-19 pandemic. The author argues that the research related to this topic during the pandemic is still scarce, while the pandemic continues to spread, and the importance of e-learning plays a vital role now more than ever. The perspective of readiness and sociology and economic factors will also be presented to investigate any relationship between them in the pandemic era concerning readiness. A total of 1.154million high-school students in the urban area and 868 students in the rural areas from 8 schools joined the survey to analyze further and discuss. Thus, the research questions conveyed in this paper are as follows:

Q1: How significant is the difference in e-learning readiness level between students in the urban and rural areas during the COVID-19 pandemic?

Q2: What factors describe the relationship between economic background and e-learning readiness of students in urban or rural areas?

Q3: What factors describe the relationship between social background and e-learning readiness of students both in urban or rural areas?

In order to answer these questions, the data from the questionnaire are extracted and analyzed based on the e-learning readiness framework from Chapnik (2000). Consequently, the score obtained from the e-learning framework is then projected to the e-learning assessment scale made by Aydin \& Tasci (2005). In the next step, the statistical analysis is conducted to see the relations between socioeconomic and e-learning readiness scores. Finally, the policy recommendation will be discussed based on the results to give perspective and future strategies.

\section{Literature Review}

\section{Understanding E-Learning}

E-Learning has become one of the most transformative learning platforms of the education sector in the 21st century. In understanding the definition of e-learning comprehensively, four aspects can be taken into account: technology-driven, communication-driven, delivery-system-oriented driven, and educational-paradigm-oriented driven. In technology-driven, e-Learning takes online school access via computer, phone, or physical interface through a modem, wireless, or cable link to the academic course material. In communication-driven communication, e-learning focuses on ICTs through pedagogical contact with the students and content, students and teachers, or between students over the Internet. While in the delivery-system-oriented driven, E-learning provides interactive learning, training, or education program delivered through the electronic channel. At last, by educationalparadigm, E-learning is leveraging modern multimedia and net technology to enhance the learning experience by enabling access to information and facilities, as well as remote sharing and collaboration (Governors State University, 2008; González-Videgaray, 2007; Li, Lau \& Dharmendran, 2009; Alonso et al., 2005 in Sangrà et al., 2012). 
In understanding the differentiation between e-learning and conventional learning, the most significant difference lies in the medium in which the materials are delivered. When we enjoy elearning traditionally, the instructor directly controls the learning process in typical contexts, including adapting, re-aligning, and modifying the lesson when needed. Several aspects affect the learning condition, such as teachers' abilities, personalities, and the ability to adapt and support materials to the learning environment. In the e-learning case, the learner is unconnected by cyberspace from the learner. There is no longer the opportunity to evolve, alter, or modify directly. This makes the block of content a very critical block when we are discussing the different methods (Hamid, 2001).

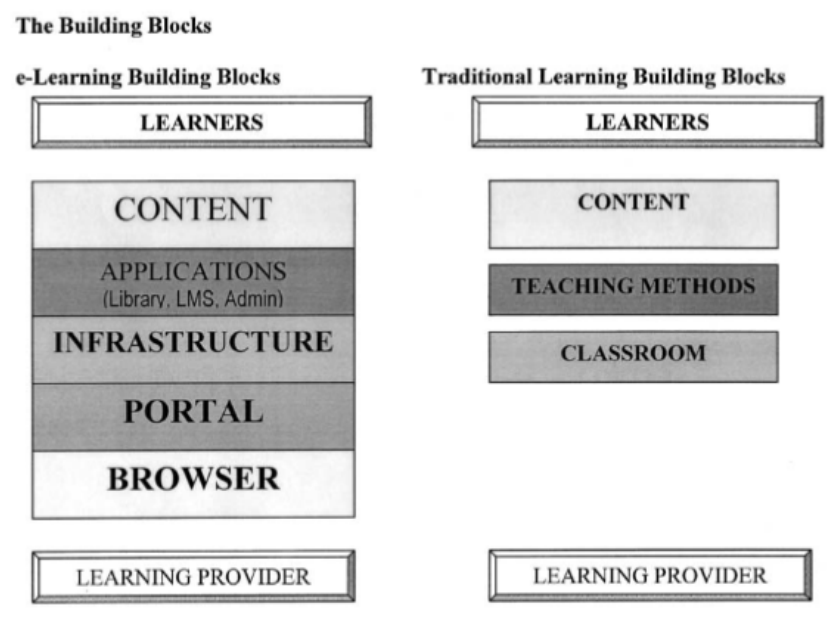

Figure 2. Building blocks of e-Learning (Hamid,2001)

\section{Measuring e-Learning Readiness}

e-Learning readiness is the institution's readiness to adopt e-learning both physically and mentally. In addition, it is one of the most significant factors for the effective delivery and success of e-learning programs (Kaur \& Abas, 2004; Rohayani et al., 2015; Mosa et al., 2016). All organizations concerning e-Learning as one platform to deliver materials to students must notice e-learning readiness (Borotis \& Poulymenakou, 2004). In order to implement and to improve efficient and effective e-learning, measurement of e-readiness is necessary. Many researchers have studied factors that can be categorized to measure e-learning. Among them are Chapnick (2000) with eight dimensions, Alaasaidik (2007) with four dimensions, Eslaminejad et al. (2010) with four dimensions, and Mavenya (2013) with five dimensions. In this paper, the author will apply Chapnick's frameworks since it covers broad aspects of e-learning, often cited by many scholars and researchers for their basis for measuring readiness (Akaslan \& Law, 2011).

Chapnick (2000) developed an e-learning measurement model which comprises eight dimensions. At initial, the design of measurement must answer these questions: can we do e-learning? If we can conduct e-learning, how about the details of e-learning itself? Are we going to do such details? And what are the outcomes of e-learning, and how can we measure them? The model will answer through eight dimensions to get essential information/the factors are categorized into eight dimensions: 
Sociological readiness. This factor considers the behavioral dimensions of the community in which the curriculum will be applied; Psychological readiness. This factor considers the participant's state of mind when it determines the result of the e-learning initiative; Environmental readiness recognizes the influence of both internal and external forces in conducting e-learning; Human Resource Readiness. This aspect considers the system's availability and architecture of the human-support system; financial readiness. This aspect represents the budget size and allocation process needed for e-learning; Technological ability/skill (aptitude) readiness. This factor considers visible and measurable technical (ICT) capabilities; Equipment readiness. This factor considers the infrastructure needs for the success of e-learning; and Content readiness. This factor considers the subject matter and purposes of teaching.

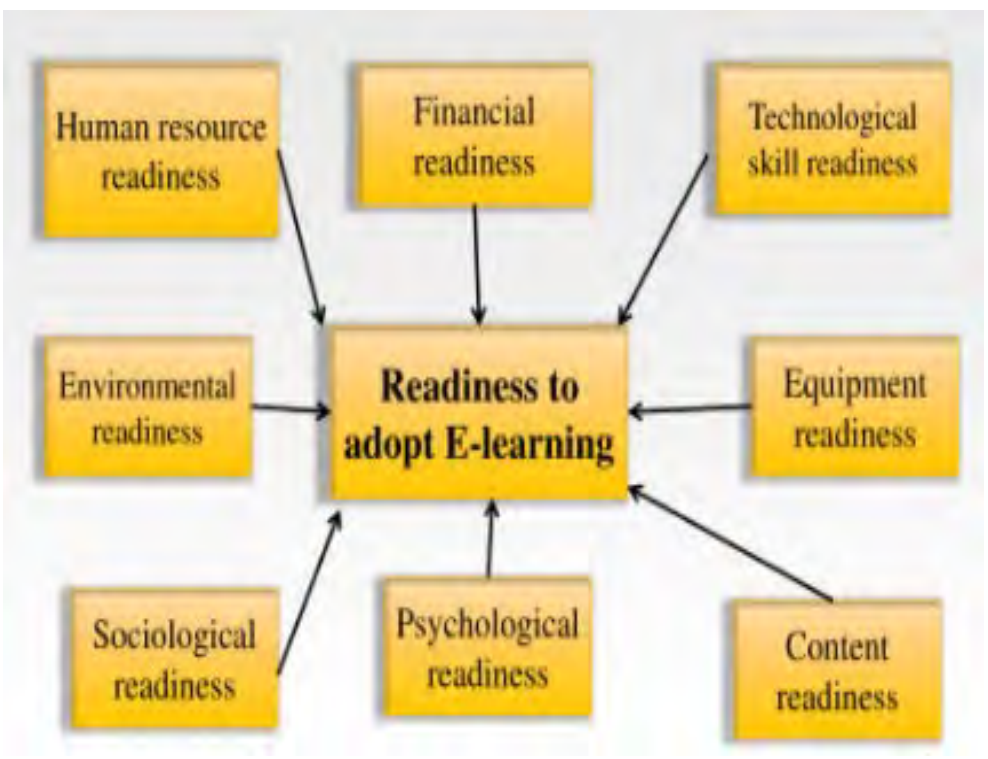

Figure 3. Eight dimensions of e-learning readiness (Chapnick, 2000)

Aydin \& Tasci (2005) developed an assessment scale for e-learning devoted to developing countries. Most Indonesian researchers also use this scale to depict the degree of readiness in the implementation of e-learning (Muharina \& Kelana, 2017). The scale comprises five categories, transformed from the Likert scale used in the questionnaire. In this paper, the author will map the eight dimensions of e-learning readiness and the accumulative score into the scale, as shown in figure 4 below.

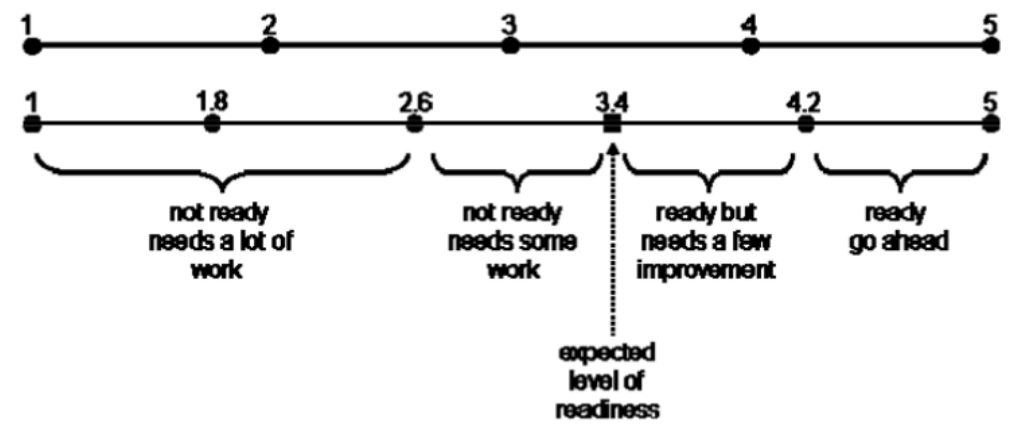

Figure 4. e-learning assessment scale (Aydin \& Tasci, 2005) 


\section{Data and Methodology}

This study aims to compare e-learning readiness in rural and urban areas and use the quantitative approach to test the given research questions. By doing so, an online questionnaire was distributed to respondents to gather the primary data for the study. The collected data will then be analyzed using multiple regression analysis. Thus, to conduct the study, the author selected four schools in the capital city and big cities in the province, and four schools in the rural area. To define which schools are categorized in a rural area, the author utilized data from the Ministry of Villages, Development of Disadvantaged Regions, and Transmigration (122 disadvantaged, frontier, and outermost areas in Indonesia 2015-2019), which later stipulated as Presidential Decree 131/2015. The law states that disadvantaged areas are regencies whose territory and society are less developed than other regions on a national scale.

Table 2: School profiles

\begin{tabular}{|c|c|c|c|c|c|c|c|c|}
\hline & $\begin{array}{l}\text { School } \\
\text { Urban A }\end{array}$ & $\begin{array}{l}\text { School } \\
\text { Urban B }\end{array}$ & $\begin{array}{l}\text { School } \\
\text { Urban C }\end{array}$ & $\begin{array}{l}\text { School } \\
\text { Urban D }\end{array}$ & $\begin{array}{l}\text { School } \\
\text { Rural A }\end{array}$ & $\begin{array}{l}\text { School } \\
\text { Rural B }\end{array}$ & $\begin{array}{l}\text { School } \\
\text { Rural C }\end{array}$ & $\begin{array}{l}\text { School } \\
\text { Rural D }\end{array}$ \\
\hline $\begin{array}{l}\text { Location of } \\
\text { School }\end{array}$ & Jakarta & Bandung & Semarang & Bandung & $\begin{array}{l}\text { Bondowoso } \\
\text { (Remote and } \\
\text { disadvantaged } \\
\text { area 2015-2019, } \\
\text { Presidential } \\
\text { Decree 131/2015) }\end{array}$ & $\begin{array}{l}\text { Bandung } \\
\text { Regency } \\
\text { (Developing } \\
\text { District, Ministry } \\
\text { of Village, 2019) }\end{array}$ & $\begin{array}{l}\text { Jeneponto } \\
\text { (Remote and } \\
\text { disadvantaged } \\
\text { area 2015-2019, } \\
\text { Presidential } \\
\text { Decree } \\
\text { 131/2015) }\end{array}$ & $\begin{array}{l}\text { Singkil, Aceh } \\
\text { (Remote and } \\
\text { disadvantaged } \\
\text { area 2015-2019, } \\
\text { Presidential } \\
\text { Decree 131/2015) }\end{array}$ \\
\hline $\begin{array}{l}\text { Accreditation } \\
\text { Predicate }\end{array}$ & $\begin{array}{c}91(\mathrm{~A}) \\
\operatorname{MoE}(2017)\end{array}$ & $\begin{array}{c}98(\mathrm{~A}) \\
\operatorname{MoE}(2018)\end{array}$ & $\begin{array}{c}99(\mathrm{~A}) \\
\operatorname{MoE}(2016)\end{array}$ & $\begin{array}{c}93(\mathrm{~A}) \\
\operatorname{MoE}(2017)\end{array}$ & - & - & $\begin{array}{c}88(B) \\
\operatorname{MoE}(2017)\end{array}$ & - \\
\hline Location & $\begin{array}{l}\text { Capital City of } \\
\text { Indonesia }\end{array}$ & $\begin{array}{c}\text { Capital City of } \\
\text { West Java }\end{array}$ & $\begin{array}{l}\text { Capital City of } \\
\text { Central Java }\end{array}$ & $\begin{array}{l}\text { Capital City of } \\
\text { Bandung Reg. }\end{array}$ & $\begin{array}{c}\text { Village } \\
( \pm 216 \mathrm{KM} \text { from } \\
\text { province capital } \\
\text { city })\end{array}$ & $\begin{array}{c}\text { Village } \\
( \pm 34 \text { KM from } \\
\text { provincial capital } \\
\text { city })\end{array}$ & $\begin{array}{c}\text { Village } \\
( \pm 84 \mathrm{KM} \text { from } \\
\text { provincial capital } \\
\text { city })\end{array}$ & $\begin{array}{c}\text { Village } \\
(+667 \mathrm{KM} \text { from } \\
\text { provincial capital } \\
\text { city })\end{array}$ \\
\hline
\end{tabular}

The research purposively selected eight schools, comprising a total population of 4.776million students in the urban area and 2.130million students in the rural area. With a margin error of $5 \%$ and a level of confidence of $95 \%$, the sample required in the urban area based on computation using Krejcie \& Morgan (1970) computation is 1.154 million, while in the rural area, the sample needed is 868 , so the total sample required is 2.022 million. In this paper, the author collected 1.260 million samples from the urban area, and 846 samples in the rural area, making a total of 2.106 million samples $(104,1 \%)$. In addition, the fulfillment of the questionnaire in the urban area is $109 \%$, while in a rural area, due to several circumstances and limitations, the questionnaire accomplishment rate is $97,5 \%$. The details of total students, projected sample, and collected data can be seen in Table 3 below. 
Moch. Bambang Sulistio / Comparative Study of E-Learning Readiness and Socio-Economic Factors During Covid-19 Pandemic: Evidence from High School Students in Urban and Rural Areas of Indonesia

Table 3: Sample size and quantification

\begin{tabular}{|c|l|c|c|c|}
\hline No & \multicolumn{1}{|c|}{ Schools } & Students & $\begin{array}{c}\text { Projected } \\
\text { Sample }\end{array}$ & Collected \\
\hline 1 & URBAN SCHOOL A & 776 & 258 & 333 \\
\hline 2 & URBAN SCHOOL B & 1.336 & 299 & 297 \\
\hline 3 & URBAN SCHOOL C & 1.245 & 294 & 313 \\
\hline 4 & URBAN SCHOOL D & 1.419 & 303 & 317 \\
\hline & Total & 4.776 & 1.154 & 1.260 \\
\hline 5 & RURAL SCHOOL A & 639 & 241 & 283 \\
\hline 6 & RURAL SCHOOL B & 288 & 165 & 175 \\
\hline 7 & RURAL SCHOOL C & 768 & 257 & 283 \\
\hline 8 & RURAL SCHOOL D & 435 & 205 & 105 \\
\hline & Total & 2130 & 868 & 846 \\
\hline & Combined Total & 6906 & 2.022 & 2.106 \\
\hline
\end{tabular}

\section{Descriptive Statistic}

\section{Population and Sampling of Study}

Table 4 represents the personal characteristics of students who were surveyed in this study. The distribution of female students who filled the survey is above $60 \%$, juxtaposed in urban and rural areas. From the gender of age, students aged 16 become the biggest respondent of this study, followed by students one year older. While from the grade, the spread of data is distributed generally in all grades, taking a portion of $30-35 \%$ in each grade.

Table 4: Personal characteristics of respondents

\begin{tabular}{|c|c|c|c|c|c|c|c|}
\hline Variables & Description & Urban Students & $\%$ & Rural Students & $\%$ & Combination & $\%$ \\
\hline \multirow[t]{3}{*}{ Gender } & Male & 432 & 34.29 & 319 & 37.71 & 751 & 35.66 \\
\hline & Female & 828 & 65.71 & 527 & 62.29 & 1355 & 64.34 \\
\hline & Subtotal & 1,260 & 100.00 & 846 & 100.00 & 2,106 & 100.00 \\
\hline \multirow[t]{6}{*}{ Age } & $<15$ & 18 & 1.43 & 82 & 9.69 & 100 & 4.75 \\
\hline & 15 & 246 & 19.52 & 159 & 18.79 & 405 & 19.23 \\
\hline & 16 & 536 & 42.54 & 255 & 30.14 & 791 & 37.56 \\
\hline & 17 & 397 & 31.51 & 236 & 27.90 & 633 & 30.06 \\
\hline & $>17$ & 63 & 5.00 & 114 & 13.48 & 177 & 8.40 \\
\hline & Subtotal & 1,260 & 100.00 & 846 & 100.00 & 2,106 & 100.00 \\
\hline \multirow[t]{4}{*}{ Grade } & 1st Grade & 382 & 30.32 & 283 & 33.45 & 665 & 31.58 \\
\hline & 2nd Grade & 447 & 35.48 & 289 & 34.16 & 736 & 34.95 \\
\hline & 3rd Grade & 431 & 34.21 & 274 & 32.39 & 705 & 33.48 \\
\hline & Subtotal & 1,260 & 100.00 & 846 & 100.00 & 2,106 & 100.00 \\
\hline
\end{tabular}

The sociological background of this study can be seen in table 5 . In the highest background of parent's education, in Urban area, almost $64 \%$ of students' parents have a high level of education compared to the rural area in which only $12 \%$. The pandemic affected students' parent jobs in rural areas, also experiencing a higher number than in urban areas. During the pandemic, almost $67 \%$ of students stayed at home in the urban area for a long time, compared to a rural area with $42 \%$. One of the causes is the zoning system applied by the Indonesian Government, where students surveyed in 
the urban area mostly live in the red zone with a high case rate of Covid-19, which strictly limits its citizen's activities to go outside. The data also shows that most students in the urban area access the Internet longer than in rural areas. This pandemic proved to negatively impact the motivation of learning, both in the urban and rural areas. While in the familiarity of e-learning before the pandemic, some $10 \%$ of students were familiar with the platform, with $13 \%$ of them being in a rural area, compared to the urban area with a lower number.

Table 5: Sociological characteristics of respondents

\begin{tabular}{|c|c|c|c|c|c|c|c|}
\hline Variables & Description & Urban Students & $\%$ & Rural Students & $\%$ & Combination & $\%$ \\
\hline \multirow[t]{3}{*}{ Parents Highest Education Backgrounds } & Low (Primary until high School) & 454 & 36.03 & 743 & 87.83 & 1,197 & 56.84 \\
\hline & High (Bachelor to Doctoral) & 806 & 63.97 & 103 & 12.17 & 909 & 43.16 \\
\hline & Subtotal & 1,260 & 100.00 & 846 & 100.00 & 2,106 & 100.00 \\
\hline \multirow[t]{3}{*}{ Job Status of Parents During Covid-19 Pandemic } & Affected & 176 & 13.97 & 290 & 34.28 & 466 & 22.13 \\
\hline & Not Affected & 1,084 & 86.03 & 556 & 65.72 & 1,640 & 77.87 \\
\hline & Subtotal & 1,260 & 100.00 & 846 & 100.00 & 2,106 & 100.00 \\
\hline \multirow[t]{4}{*}{ Student average staying at home } & Short (0-5 hrs.) & 57 & 4.52 & 348 & 41.13 & 405 & 19.23 \\
\hline & Medium (6-15 hrs.) & 358 & 28.41 & 138 & 16.31 & 496 & 23.55 \\
\hline & Long (16-24 hrs.) & 845 & 67.06 & 360 & 42.55 & 1,205 & 57.22 \\
\hline & Subtotal & 1,260 & 100.00 & 846 & 100.00 & 2,106 & 100.00 \\
\hline Variables & Description & Urban Students & $\%$ & Rural Students & $\%$ & Combination & $\%$ \\
\hline \multirow[t]{4}{*}{ Average accessing Internet at home } & Short (0-2 hrs) & 8 & 0.63 & 90 & 10.64 & 98 & 4.65 \\
\hline & Medium (2-6 hrs) & 203 & 16.11 & 434 & 51.30 & 637 & 30.25 \\
\hline & Long (>6 hrs) & 1049 & 83.25 & 322 & 38.06 & 1371 & 65.10 \\
\hline & Subtotal & 1,260 & 100 & 846 & 100 & 2,106 & 100.00 \\
\hline \multirow[t]{4}{*}{ Students Motivation since online learning started } & Decreasing & 633 & 50.24 & 437 & 51.65 & 1070 & 50.81 \\
\hline & Stagnant & 519 & 41.19 & 358 & 42.32 & 877 & 41.64 \\
\hline & Increasing & 108 & 8.57 & 51 & 6.03 & 159 & 7.55 \\
\hline & Subtotal & 1,260 & 100 & 846 & 100 & 2,106 & 100.00 \\
\hline \multirow[t]{4}{*}{ Familiarity of students with online learning before pandemic } & Didn't know at all & 367 & 29.13 & 355 & 41.96 & 722 & 34.28 \\
\hline & Heard but rarely use it & 801 & 63.57 & 374 & 44.21 & 1175 & 55.79 \\
\hline & Already familiar & 92 & 7.30 & 117 & 13.83 & 209 & 9.92 \\
\hline & Subtotal & 1,260 & 100 & 846 & 100 & 2,106 & 100.00 \\
\hline
\end{tabular}

The economic characteristics of students can be seen in table 6. There is a huge gap between students in urban and rural areas regarding device ownership for implementing online learning. Most students in the city area own more than one device to conduct e-learning, while most students depend on a onesingle device in the rural area. The capacity of infrastructure juxtaposed urban and rural area also differs them to connect to the web, whereas students who live in the city have greater broadband access. In terms of salary during the pandemic, most parents live in a rural area with a lower salary than in the urban area. Most of the parents grouped in medium to a high salary. This factor might also lead to the money spent on distance learning, which differs between the two regions. 
Moch. Bambang Sulistio / Comparative Study of E-Learning Readiness and Socio-Economic Factors During Covid-19 Pandemic: Evidence from High School Students in Urban and Rural Areas of Indonesia

Table 6: Economic characteristics of respondents

\begin{tabular}{|c|c|c|c|c|c|c|c|}
\hline Variables & Description & Urban Students & $\%$ & Rural Students & $\%$ & Combination & $\%$ \\
\hline \multirow[t]{4}{*}{ Devices for support online learning } & Not adequate (not at all) & 1 & 0.08 & 11 & 130 & 12 & 0.57 \\
\hline & Adequate (1 device) & 283 & 22.46 & 744 & 87.94 & 1,027 & 48.77 \\
\hline & Very Adequate (More than 1 devices) & 976 & $\pi, 46$ & 91 & 10.76 & 1,067 & 50.66 \\
\hline & Subtotal & 1,260 & 100.00 & 846 & 100.00 & 2,106 & 100.00 \\
\hline \multirow[t]{4}{*}{ Internet connection at home } & Not adequate (not at all) & 4 & 0.32 & 12 & 1.42 & 16 & 0.76 \\
\hline & Adequate $(2 \mathrm{G}-4 \mathrm{G}$ connections $)$ & 536 & 4254 & 775 & 91.61 & 1,311 & 6225 \\
\hline & Very Adequate (Broadband) & 720 & 57.14 & 59 & 6.97 & 79 & 36.99 \\
\hline & Subtotal & 1,260 & 100.00 & 846 & 100.00 & 2,106 & 100.00 \\
\hline \multirow[t]{4}{*}{ Parents Salary during pandemic } & Low (33 Million Rupiahs) & 388 & 30.79 & 739 & 87.35 & 1,127 & 53.51 \\
\hline & Medium (3-10 Million Rupiahs) & 613 & 48.65 & 103 & 12.17 & 716 & 34.00 \\
\hline & High (>10 Million Rupiahs) & 259 & 20.56 & 4 & 0.47 & 263 & 12.49 \\
\hline & Subtotal & 1,260 & 100.00 & 846 & 100.00 & 2,106 & 100.00 \\
\hline \multirow[t]{4}{*}{ Salary spent for online learning } & Low (0-500 Thousand Rupiahs) & 581 & 46.11 & 555 & 65.60 & 1,136 & 53.94 \\
\hline & Medium (500 Thousand-1 Milion Rupiahs) & 421 & 33.41 & 225 & 26.60 & 646 & 30.67 \\
\hline & High (>1 Million Rupiahs) & 258 & 20.48 & 66 & 7.80 & 324 & 15.38 \\
\hline & Subtotal & 1,260 & 100.00 & 846 & 100.00 & 2,106 & 100.00 \\
\hline
\end{tabular}

\section{Result and Analysis}

\section{E-Learning readiness}

The result of e-learning readiness shows in table 7. Overall, there is a difference between students who live in urban and rural areas in the overall e-learning index. Students in urban areas are categorized as ready with few improvements, but students in rural areas are not ready and need some work to make it ready. Outside psychological readiness, all indicators show that students in urban areas have higher scores than the rural area. The most significant gap identified from the indicator comes from technological skill (1, 41 points), equipment readiness $(0,81$ points), and financial readiness $(0,80$ points). One finding that needs to take into account by education stakeholders is that no indicators reach "ready to go (>4, 2 points)" in all indicators, either in the urban or rural area.

Figure 7: Result of e-learning readiness

\begin{tabular}{|c|c|c|c|c|c|}
\hline No & Factors & Urban Students & Readiness & Rural Students & Readiness \\
\hline & & Index & Interpretation & Index & Interpretation \\
\hline & $\mathbf{N}$ & 1.260 & & 846 & \\
\hline 1 & Financial readiness & 4.00 & $\begin{array}{l}\text { Ready but needs a } \\
\text { few improvement }\end{array}$ & 3.19 & $\begin{array}{l}\text { Not ready needs } \\
\text { some work }\end{array}$ \\
\hline 2 & Equipment readiness & 3.82 & $\begin{array}{l}\text { Ready but needs a } \\
\text { few improvement }\end{array}$ & 2.98 & $\begin{array}{l}\text { Not ready needs } \\
\text { some work }\end{array}$ \\
\hline 3 & Technological skill & 3.78 & $\begin{array}{l}\text { Ready but needs a } \\
\text { few improvement }\end{array}$ & 2.34 & $\begin{array}{l}\text { Not ready needs a lot } \\
\text { of works }\end{array}$ \\
\hline 4 & Content readiness & 3.35 & $\begin{array}{l}\text { Not ready needs some } \\
\text { work }\end{array}$ & 3.23 & $\begin{array}{l}\text { Not ready needs } \\
\text { some work }\end{array}$ \\
\hline 5 & Human resource readiness & 3.25 & $\begin{array}{l}\text { Not ready needs some } \\
\text { work }\end{array}$ & 2.93 & $\begin{array}{l}\text { Not ready needs } \\
\text { some work }\end{array}$ \\
\hline 6 & Environmental readiness & 3.32 & $\begin{array}{l}\text { Not ready needs some } \\
\text { work }\end{array}$ & 3.27 & $\begin{array}{l}\text { Not ready needs } \\
\text { some work }\end{array}$ \\
\hline 7 & Psychological readiness & 2.85 & $\begin{array}{l}\text { Not ready needs some } \\
\text { work }\end{array}$ & 2.92 & $\begin{array}{l}\text { Not ready needs } \\
\text { some work }\end{array}$ \\
\hline \multirow[t]{2}{*}{8} & Sociological readiness & 3.47 & $\begin{array}{l}\text { Ready but needs a } \\
\text { few improvement }\end{array}$ & 3.30 & $\begin{array}{l}\text { Not ready needs } \\
\text { some work }\end{array}$ \\
\hline & E-Learning readiness Index & 3.47 & $\begin{array}{l}\text { Ready but needs a } \\
\text { few improvement }\end{array}$ & 3.01 & $\begin{array}{l}\text { Not ready needs } \\
\text { some work }\end{array}$ \\
\hline
\end{tabular}


Figure 5 indicates data from all the students when it breaks out by categorical form. Some $54 \%$ of students in urban areas are categorized as ready to adopt e-learning. However, in a rural area, the number is about $21 \%$. Students in the rural area mainly concentrated in the category not prepared and need some works. More than $18 \%$ of students in the area are also not ready with many works required.

\begin{tabular}{|c|c|c|c|c|}
\hline \multirow{2}{*}{ Category } & \multicolumn{2}{|c|}{ Urban Students } & \multicolumn{2}{c|}{ Rural Students } \\
\cline { 2 - 5 } & $\mathrm{N}$ & $\%$ & $\mathrm{~N}$ & $\%$ \\
\hline Not Ready need a lot of work & 61 & 4.8 & 159 & $\mathbf{1 8 . 8}$ \\
\hline Not ready need some works & 516 & $\mathbf{4 1 . 0}$ & 507 & $\mathbf{5 9 . 9}$ \\
\hline Ready but needs a few improvement & 572 & 45.4 & 169 & 20.0 \\
\hline Ready go ahead & 111 & 8.8 & 11 & 1.3 \\
\hline Total & 1260 & & 846 & \\
\hline
\end{tabular}

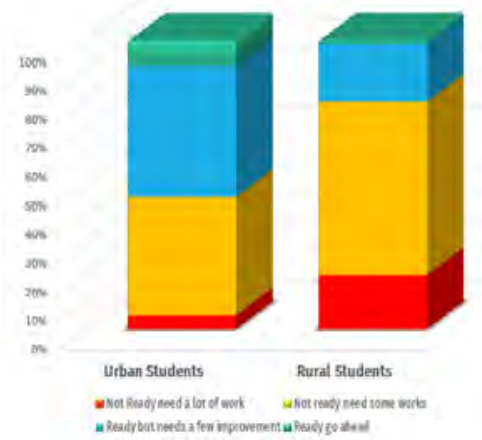

Figure 5. Breakout data of students based on readiness

\section{Statistical Analysis: Socio-Economic Factors}

Table 8 shows the results of the regression analysis between socio-economic factors with e-learning readiness. When the regression was conducted partially, the results of significance are as follows: In rural areas, grades correlated negatively to e-learning readiness. It means the higher grade of students, the lower score of readiness. While in urban areas, the higher parents' education level of students positively impacts e-learning readiness. Some factors that influence urban and rural areas are students' motivation towards e-learning, the familiarity of e-learning beforehand, and devices supporting e-learning. In addition, parents' salary and their expenditures for e-learning also play essential factors in driving e-learning readiness in urban areas.

Table 8: Result of regression

\begin{tabular}{|c|c|c|c|c|c|c|}
\hline \multirow{2}{*}{ Independent Variable } & \multicolumn{3}{|c|}{ Model 1: Urban Students } & \multicolumn{3}{c|}{ Model 2: Rural Students } \\
\cline { 2 - 8 } & Coef. & Std. Err. & T-value & Coef. & Std. Err. & T-value \\
\hline Gender & -0.02 & 0.03 & -0.85 & 0.04 & 0.02 & 1.71 \\
Grade & -0.04 & 0.03 & -1.49 & $-0.08^{\star *}$ & 0.03 & -2.6 \\
\hline Parents Highest Education Backgrounds & $0.09^{\star *}$ & 0.03 & 2.99 & 0.08 & 0.06 & 1.3 \\
\hline Job Status During Covid-19 Pandemic & 0.05 & 0.04 & 1.45 & $0.08^{\star}$ & 0.04 & 2.24 \\
\hline Average staying at home & 0.04 & 0.02 & 1.58 & $-0.04^{*}$ & 0.02 & -2.29 \\
\hline Average accessing Internet at home & -0.04 & 0.03 & -1.17 & 0.03 & 0.03 & 0.92 \\
\hline Students Motivation Towards e-Learning & $0.23^{\star * *}$ & 0.02 & 11.57 & $0.14^{\star * *}$ & 0.03 & 5.06 \\
\hline Familiarity of e-Learning beforehand & $0.10^{\star * *}$ & 0.02 & 4.59 & $0.08^{\star *}$ & 0.02 & 3.06 \\
\hline Devices for support online learning & $0.24^{\star \star *}$ & 0.03 & 6.91 & $0.32^{\star * *}$ & 0.05 & 5.8 \\
\hline Internet connection at home & $0.14^{* * *}$ & 0.03 & 5.01 & 0.10 & 0.06 & 1.68 \\
\hline Parents Salary during pandemic & $0.11^{\star * *}$ & 0.02 & 4.93 & $0.11^{\star}$ & 0.05 & 1.99 \\
\hline Salary spent for online learning & $-0.05^{* *}$ & 0.02 & -3.06 & -0.05 & 0.03 & -1.8 \\
\hline
\end{tabular}

Significance ${ }^{*} \mathrm{p}<0.10,{ }^{* *} \mathrm{p}<0.05,{ }^{* * *} \mathrm{p}<0.01$ 
Moch. Bambang Sulistio / Comparative Study of E-Learning Readiness and Socio-Economic Factors During Covid-19 Pandemic: Evidence from High School Students in Urban and Rural Areas of Indonesia

\section{Results of Each Dimension on Socio-Economic}

Based on each dimension's statistical analysis through socio-economic factors, all dimensions prove statistically significant, with most of the variables having a positive coefficient. However, some negative variables attracted the attention of authors as follows:

\section{Salary Spent Higher in E-Learning, Students Still Not Tech-Savvy}

Based on the regression result of salary spent on e-learning to all readiness, the authors found that the wage paid on online learning contributed negatively to technological readiness. Several reasons could be the cause. Firstly, parents' awareness in Indonesia to give their kids training in the ICT field is related low, especially in the rural area where the infrastructure is also limited. That is why the average index of technological skill is categorized as not ready and needs a lot of work. In addition, most budget spent on e-learning in Indonesia is spent on buying the Internet quota, and parents did not pay much attention to their kids on how to operate the new technologies (Detik, 2020).

\section{Students Staying at Home and Accessing Internet Too Long contributed negatively to Psychological Readiness}

From this study, the author also found that the longer students stay at home and access the net, the lower their psychological readiness to e-learning. Syatiri (2020) posited what might be the cause. Students face a change that they didn't expect to happen during distance learning. In such a speedy time, the students lost their daily lives from going to school, having face-to-face interaction with teachers and friends physically, playing with friends, etc. Also, the emotional connection between the child and the teacher and classmates will inevitably disrupt the social learning process or the students' socialization.

\section{Conclusion and Policy Recommendations}

Coronavirus pandemic has affected education stakeholders to make transformational changes in learning delivery. Since the Government worldwide mainly chose the Internet as the primary policy to deliver content in distance learning, the role of e-learning has become more critical than ever. Students' e-Learning readiness differs based on the area in Indonesia. In the urban area, students are categorized as ready but need some improvements. In contrast, students who are living in rural areas are not prepared and also need some improvements. Thoroughly, students in urban areas are categorized as not ready and need some improvements in content readiness, human resource readiness, environmental readiness, and psychological readiness. While in rural areas, all eight aspects are categorized as not ready and technological skill become the one that is not ready and requires a lot of improvements. Socio-economic factors have statistically proven to impact e-learning readiness in urban and rural areas.

The socio-economic factors influencing e-Learning readiness in urban and rural areas are students' motivation toward e-learning, the familiarity of e-learning, and devices support for e-learning. Also, Internet connection at home, parents' salaries, and money spent on e-learning affect e-learning readiness in the urban area. These variables are caused by more variance data from students surveyed in the urban area.

Compared to the urban area, where the data have more variability, rural areas tend to be homogenous as infrastructure, salary, and money spent on online learning are primarily grouped in specific numbers. Based on each dimension regression, it is found that the money paid for e-learning correlated negatively with technological readiness. It is mainly because of the lack of infrastructure, parent awareness, and priority of spending. Another fact that can be inferred is that the longer 
Moch. Bambang Sulistio / Comparative Study of E-Learning Readiness and Socio-Economic Factors During Covid-19 Pandemic: Evidence from High School Students in Urban and Rural Areas of Indonesia

students stay at home, the longer they access the Internet; psychological readiness is also negatively affected.

\section{Rural Students need more ICT Competence Training}

This study reveals a significant gap in e-learning readiness in an urban area compared to rural areas (3, 78 to 2,34). Students in rural areas are urged to have ICT competence training. It is because they are categorized as not ready and need many improvements. The basic ICT skills being investigated in this research are whether students can have basic skills to operate a computer, install software on either PC or mobile, able to use functional features of video conference, good to operate any office applications, send email as well as to find any information on the Internet. This should be taken into account by the Government, education office, and schools' stakeholders to give the necessary skills of ICT competence to make sure students also can enjoy the content of online learning. Of course, infrastructure enhancement and ICT facilities also need to be improved simultaneously with the training.

\section{Limitations and Future Research}

This study concentrates mainly on big cities like Jakarta, Bandung, and Semarang, all located in Java Island as the sample of schools being investigated. Further research can search for a broader context of the cities, focusing on Java Island. Future studies might also analyze whether ICT training will significantly impact their perceives and acceptance of students' e-learning readiness, especially in rural areas after training has been conducted.

\section{References}

Akaslan, D., \& Law, E. L.-C. (2011). Measuring Student E-Learning Readiness: A Case about the Subject of Electricity in Higher Education Institutions in Turkey. Advances in Web-Based Learning - ICWL 2011, 209218. https://doi.org/10.1007/978-3-642-25813-8_22

Alqahtani, A. Y., \& Rajkhan, A. A. (2020). E-Learning Critical Success Factors during the COVID-19 Pandemic: A Comprehensive Analysis of E-Learning Managerial Perspectives. Education Sciences, 10(9), 216. https://doi.org/10.3390/educsci10090216

Ansari, M. A., \& Yogita, N. (2020, July 17). A Comparative Study of e-Learning Readiness of Two State Agricultural Universities (SAUs) in Northern India. ResearchGate; unknown. https://www.researchgate.net/publication/343040744_A_Comparative_Study_of_e-

Learning_Readiness_of_Two_State_Agricultural_Universities_SAUs_in_Northern_India

Atanda, B. N., \& Ahlan, A. R. (2014). Issues of e-learning in developing countries: A Nigerian perspective. The 5th International Conference on Information and Communication Technology for the Muslim World (ICT4M). https://doi.org/10.1109/ict4m.2014.7020626

Aung, T. N., \& Khaing, S. S. (2015). Challenges of Implementing e-Learning in Developing Countries: A Review. Advances in Intelligent Systems and Computing, 405-411. https://doi.org/10.1007/978-3-319-232072_41

Aydin, C. H., \& Tasci, D. (2005). Measuring Readiness for e-Learning: Reflections from an Emerging Country. ResearchGate; International Forum of Educational Technology and Society. https://www.researchgate.net/publication/220374121_Measuring_Readiness_for_eLearning_Reflections_from_an_Emerging_Country 
Moch. Bambang Sulistio / Comparative Study of E-Learning Readiness and Socio-Economic Factors During Covid-19 Pandemic: Evidence from High School Students in Urban and Rural Areas of Indonesia

Borotis, S., \& Poulymenakou, A. (2004). E-Learning Readiness Components: Key Issues to Consider Before Adopting e-Learning Interventions. Association for the Advancement of Computing in Education (Aace. https://www.learntechlib.org/p/11555/

Central Bureau of Statistic. (2018). Badan Pusat Statistik. Bps.Go.Id. https://www.bps.go.id/publication/2018/12/24/27971845a9d616341333d103/penggunaan-dan-pemanfaatanteknologi-informasi-dan-komunikasi--p2tik--sektor-pendidikan-2018.html

Detik. (2020, June 17). Ortu Siswa Mengeluh Boros Kuota, Kemendikbud Punya Solusi “Keluar Jaringan.” Detiknews; detikcom. https:/news.detik.com/berita/d-5058003/ortu-siswa-mengeluh-boros-kuotakemendikbud-punya-solusi-keluar-jaringan

Eslaminejad, T., Masood, M., \& Ngah, N. A. (2010). Assessment of instructors' readiness for implementing elearning in continuing medical education in Iran. Medical Teacher, 32(10), e407-e412. https://doi.org/10.3109/0142159x.2010.496006

Hamid, A. A. (2001). E-Learning. The Internet and Higher Education, 4(3-4), 311-316. https://doi.org/10.1016/s1096-7516 (01)00072-0

Hillier, M. (2018). Bridging the digital divide with off-line e-learning. Distance Education. https://www.tandfonline.com/doi/abs/10.1080/01587919.2017.1418627

Hoq, M. Z. (2020). E-Learning during the Period of Pandemic (COVID-19) in the Kingdom of Saudi Arabia: An Empirical Study. American Journal of Educational Research, 8(7), 457-464. http://www.sciepub.com/EDUCATION/abstract/12018

Ingrams, A., Manoharan, A., Schmidthuber, L., \& Holzer, M. (2017). Stages and Determinants of EGovernment Development: A Twelve-Year Longitudinal Study of Global Cities. International Public Management Journal. https:/www.tandfonline.com/doi/full/10.1080/10967494.2018.1467987

ITU. (2017). ITU | 2017 Global ICT Development Index. Itu.Int. https://www.itu.int/net4/ITU-D/idi/2017/

Kaur, K., \& Abas, Z. W. (2004). An assessment of e-learning readiness at Open University Malaysia. ResearchGate; unknown. https://www.researchgate.net/publication/228651396_An_assessment_of_elearning_readiness_at_Open_University_Malaysia

Krejcie, R. V., \& Morgan, D. W. (1970). Determining Sample Size for Research Activities. Educational and Psychological Measurement, 30(3), 607-610. https://doi.org/10.1177/001316447003000308

Mafenya, P. N. (2013). An Investigation of First-Year Students' Pedagogical Readiness to E-Learning and Assessment in Open and Distance Learning: A University of South Africa Context. Mediterranean Journal of Social Sciences, 4(13), 353. https://www.mcser.org/journal/index.php/mjss/article/view/1522

Maldonado, U. P. T., Khan, G. F., Moon, J., \& Rho, J. J. (2010). E-learning motivation and educational portal acceptance in developing countries | Emerald Insight. Online Information Review. https://doi.org/10.1108Voir

MoE. (2020, August 12). Menuju Transformasi Digital Pendidikan Indonesia | Pusdatin. Kemdikbud.Go.Id. https://pusdatin.kemdikbud.go.id/menuju-transformasi-digital-pendidikan-indonesia/

Mosa, A. A., Naz'ri bin Mahrin, Mohd., \& Ibrrahim, R. (2016). Technological Aspects of E-Learning Readiness in Higher Education: A Review of the Literature. Computer and Information Science, 9(1), 113. https://doi.org/10.5539/cis.v9n1p113

Muharina, A. S., \& Kelana, B. (2017). E-leaming readiness measurement on Indonesian student from individual perspective: A case study. 2017 International Conference on Sustainable Information Engineering and Technology (SIET). https://doi.org/10.1109/siet.2017.8304163 
Moch. Bambang Sulistio / Comparative Study of E-Learning Readiness and Socio-Economic Factors During Covid-19 Pandemic: Evidence from High School Students in Urban and Rural Areas of Indonesia

Qureshi, I. A., Khola Ilyas, Yasmin, R., \& Whitty, M. (2020). Challenges of implementing e-learning in a Pakistani university. Knowledge Management \& E-Learning: An International Journal, 4(3), 310-324. http://www.kmel-journal.org/ojs/index.php/online-publication/article/view/173

Rohayani, A. H. H., Kurniabudi, \& Sharipuddin. (2015). A Literature Review: Readiness Factors to Measuring e-Learning Readiness in Higher Education. Procedia Computer Science, 59, $230-234$. https://doi.org/10.1016/j.procs.2015.07.564

Sangrà, A., Vlachopoulos, D., \& Cabrera, N. (2012). Building an inclusive definition of e-learning: An approach to the conceptual framework. The International Review of Research in Open and Distributed Learning, 13(2), 145. https://doi.org/10.19173/irrodl.v13i2.1161

Sife, A., Lwoga, E., \& Camilius Sanga. (2007). New technologies for teaching and learning: Challenges for higher learning institutions in developing countries. International Journal of Education and Development Using ICT, 3(2), 57-67. https://www.learntechlib.org/p/42360/

Ssekakubo, G., Suleman, H., \& Marsden, G. (2011). Issues of adoption | Proceedings of the South African Institute of Computer Scientists and Information Technologists Conference on Knowledge, Innovation and Leadership in a Diverse, Multidisciplinary Environment. Acm.org. https://dl.acm.org/doi/10.1145/2072221.2072248

Statistikian. (2014, March 30). Penjelasan Analisis Faktor - PCA dan CFA - Uji Statistik. Uji Statistik. https://www.statistikian.com/2014/03/analisis-faktor.html

Syatiri, A. S. (2020, July 27). Dampak Psikologis pada Anak yang Sekolah dari Rumah Halaman all Kompas.com. KOMPAS.com; Kompas.com. https://www.kompas.com/tren/read/2020/07/28/065652165/dampak-psikologis-pada-anak-yang-sekolah-darirumah?page $=$ all

UN. (2020). UN E-Government Survey 2020. Un.org. https://publicadministration.un.org/egovkb/enus/Reports/UN-E-Government-Survey-2020

UNESCO. (2020, March 9). National learning platforms and tools. UNESCO. https://en.unesco.org/covid19/educationresponse/nationalresponses\#AFRICA

UNICEF. (2020a). Keeping the world's children learning through COVID-19. Unicef.org. https://www.unicef.org/coronavirus/keeping-worlds-children-learning-through-covid-19

UNICEF. (2020b, August 26). COVID-19 and School Closures: Are children able to continue learning UNICEF DATA. UNICEF DATA. https://data.unicef.org/resources/remote-learning-reachability-factsheet/

World Bank. (2020). Individuals using the Internet (\% of population) | Data. Worldbank.org. https://data.worldbank.org/indicator/IT.NET.USER.ZS 